\title{
Correction to: The measure mix matters: multiple-component plant protection is indispensable for coping with the enormous genome plasticity and mutation rates in pathogenic microorganisms
}

\author{
Ely Oliveira-Garcia ${ }^{1} \cdot$ Andreas von Tiedemann $^{2} \cdot$ Holger B. Deising ${ }^{3}$
}

Published online: 8 January 2021

(c) Deutsche Phytomedizinische Gesellschaft 2020

\section{Correction to: Journal of Plant Diseases and Protection https://doi.org/10.1007/s41348-020-00404-z}

In the original publication of the article, the first author name is incorrectly published as "Ely Oliceira-Garcia" but the correct name should read as "Ely Oliveira-Garcia".

This has been corrected in this paper.

Publisher's Note Springer Nature remains neutral with regard to jurisdictional claims in published maps and institutional affiliations.

The original article can be found online at https://doi.org/10.1007/ s41348-020-00404-z.

Holger B. Deising

holger.deising@landw.uni-halle.de

Ely Oliveira-Garcia

eoliveiragarcia@agcenter.lsu.edu

Andreas von Tiedemann

atiedem@gwdg.de

1 Department of Plant Pathology and Crop Physiology,

College of Agriculture, Louisiana State University

Agricultural Center, 302 Life Sciences Building,

Baton Rouge, LA 70803, USA

2 Chair for Plant Pathology and Crop Protection, Department

of Crop Science, Faculty of Agricultural Sciences,

Georg-August University Göttingen, Grisebachstr. 6,

37077 Göttingen, Germany

3 Chair for Phytopathology and Plant Protection, Institute for Agricultural and Nutritional Sciences, Faculty of Natural Sciences III, Martin-Luther-University Halle-Wittenberg, Betty-Heimann-Str. 3, 06120 Halle (Saale), Germany 